\title{
A Research Review on the Global Refocusing on African Development: Challenges and Opportunities in $21^{\text {st }}$ Century
}

\author{
Ignatius Nnaemeka Onwuatuegwu, PhD \\ Philosophy Department, Faculty of Arts, \\ Nnamdi Azikiwe University Awka, Nigeria
}

Doi:10.19044/esj.2020.v16n20p129 URL:http://dx.doi.org/10.19044/esj.2020.v16n20p129

\begin{abstract}
In recent years, there has been a series of supports by the developed world towards securing effective and efficient development in Africa. These support programmes have cut across various sectors, ranging from education, health and sociopolitical programmes initiated by the developed countries aimed at assisting Africa to measure up with in terms of developmental aspects with other continents. To this end, this research paper is a philosophical review that sought to centre on global refocusing on African development unveiling the challenges and opportunities faced by African continent in this $21^{\text {st }}$ century. This paper maintained that the achievability of Africa's developmental stride depends to a more significant extent on its political development. The discovered challenges include among others; bribery and corruption, bad governance, weak political institutions, and undemocratic values. These hurdles are hazardous, real and numerous but could be addressed through improvement and strengthening of governance and democracy. The significance of this research cannot be overemphasized as the issues raised in this paper could be beneficial to both policymakers and scholars alike as it will enable them to ascertain the problems and policy recommendations to avert the evils that befell the continent. Some African countries did well with regards to governance and combating corruption. However, major institutional reform is needed to achieve sustainable development across the continent. The researcher recommend that; Policies should be made towards strengthening economic analysis and management across Africa as it will to a great extent facilitate sustainable development and poverty reduction across African. This paper, therefore, will employ the analytic approach to examine the situations that stagnate African development and then make recommendations on how to surmount the problems.
\end{abstract}

Keywords: Africa, global, refocusing, developments, opportunities, century 


\section{Introduction}

In recent time, developed countries of the world have shown a massive interest in the African continent. Historically, the development of Africa has been characterized by many twists and turns. Independence in the late 1950s and most of the 1960s brought about by resistance to colonial sociopolitical and economic relations. Almost thirty years after the independence, ambitions for a New International Economic Order (NIEO) were driven by a desire to have an autonomous postcolonial development, Africa inclusive. The debt problem or crisis, by undermining the financial space coupled with tightening the dependence of the developing to the developed world, killed the unity necessary for the achievement of the NIEO as then conceived (Radice, 2011).

Numerous initiatives and attempts at new alliances were undertaken in a bid to break what was considered a dependent relationship between the global South and the 'imperial North', including the declaration of economic development as a human right recognition of the links between rights violations, conflict, poverty, exclusion, vulnerability, and failure to achieve development in its multidimensional form. Development was increasingly couched in the context of human freedom and the analysis of poverty put in a multidimensional context.

In the year 2000, the Millennium Development Goals (MDGs) were born as a global compact to deliver this new vision of development across Africa and the world in general. As it stands, rapid economic growth and development have spread from Southeast Asia to Latin America, and now Africa. As old capitalist industrialist is mired in economic stagnation and fiscal crisis, some of the 'emerging economies' are faced with investment glut resulting from the increased activities of investors seeking for a new outlet for 'redundant' capital (Radice, 2011).

Radice (2011) maintained that "the current trends in the world economy and global politics provide evidence that the global South has now arrived at 'normal' capitalism (characterized by heightened conflict between labour and capital), at last bringing with it new patterns of uneven development, inequality and injustice". Therefore, its newly confident élites, now fully engaged in global circuits of trade, investment and finance, and in global governance too, appear to have left behind their previous colonialcomprador role of serving the interests of 'imperial' capital (Radice, 2011). A trend which has brought with it the death of 'developmentalism', the irrelevance of the notion of a developmental state. I contend that, looking at the patchy and uneven way the MDGs have been delivered across Africa and the pressure as well as an agency for change that gives room for inclusive and sustainable (green) development.

Though Africa is going through its most dynamic growth period in recent times, the continent has achieved a growth rate above 6 per cent for 
most of the past decade, which presents Africa as one of the fastest-growing regions in the world today (The World Bank, 2014). Despite continuing global financial turmoil, Africa can continue its outstanding growth performance for several reasons. The emergence of Africa's middle class, placed more Africans in a position to make consumer choices, and making Africa an increasingly attractive market, for both domestic and foreign investors. Africa is currently making progress on a wide range of development frontiers. Poverty rates are drastically falling, the private sector environment is improving rapidly, trade is expanding, and more and more people are becoming connected to roads, electricity, IT, water and sanitation. Education and health are making steady progress, and the number of fragile states has declined. The underdevelopment that Africa is known for in the 1980s and 1990s has now been a thing of the past. From the early 2000s, Africa has seen the most prolonged and most 'sustained' expansion in over 50 years. It has been termed 'lions on the move. At this period, two very different development experiences have unfolded in tandem (The World Bank, 2012).

The first version is the rapid appreciation in the GDP, maintaining an average of 5 per cent a year until the 2008-09 global economic crisis. Since 2010, growth has resumed and is expected to increase to over 5 per cent in 2015 (The World Bank, 2014; UNDESA, 2014). The growth has been widespread, which results in the 22 non-oil-importing countries averaged 4 per cent growth or higher for the decade 1998-2008. Africa has been able to attract significant global investors who have facilitated private capital flows, which now exceed foreign aid. Foreign direct investment (FDI) has appreciated from US \$11 billion in 2002 to US \$57 billion in 2013 compared to foreign aid increasing from US \$18 billion to US $\$ 43$ billion over this same period (UNCTAD, 2003, 2014). The absolute poverty rate has been falling faster than 1.5 percentage point a year. For the first time, between 2005 and 2008, the absolute number of people living on US $\$ 1.25$ a day fell (by about 9 million) in many African.

According to Solheim (2017), the Commission of the Development Commissioner Poul Nielsen promptly occupied with a general update of development strategies. By April 2000, the Commission had just given an announcement on development strategy which laid out a complete way to deal with advancement of Africa, concentrated on neediness decrease. The statement on development approach, and a resulting joint Council and Commission explanation, built up neediness decrease as the focal target of EC development programmes and other EC arrangements in creating nations. In May 2000 an underlying change programme was illustrated to improve the quality and speed of conveyance of undertakings, guarantee sound money related administration, and increment the effect of European advancement help. In February, and afterward in May 2001, the Commission created a 
moving system of activity, obviously setting out the change program as far as points, activities, anticipated outcomes, a characteristic plan, and the advancement made.

As respects programming and the arranging of development intercessions, the key development was the foundation of rules for the creation of Country and Regional Strategy Papers. As another way to deal with programming, Country Strategy Papers (CSPs) should concentrate on neediness, to be complete, to underline nation proprietorship, to advance work-sharing and complementarily, to include counsel with common society associations, to concentrate on a predetermined number of regions, and to fuse various cross-cutting issues, for example, human rights, sexual orientation equity, and natural concerns. Further, an Inter-administration Quality Support Group (IQSG) was accused of investigating the methodology papers and advancing best practice (Solheim, 2017).

On 1 January 2001, Europe Aid Cooperation Office was built up as a solitary division to deal with the EC's outside guide, except for predevelopmental programmes, helpful exercises, full scale budgetary guide, the Common Foreign and Security Policy, and the Rapid Reaction Facility. The expectation was to excuse the administration and execution of advancement help, by moving further away from a geological task of obligations to various directorates and incorporating the different phases of the venture cycle in Africa. DG Development and DG External Relations were presently accused of the programming period of the venture cycle - arrangement and systems for ACP and non-ACP nations individually, while Europe Aid was liable for the staying five phases of the task cycle, directly through to assessment.

There is proof that the minor job of MDG-related segments, especially instruction and well-being include that; while moving from talk to strategy practice-the EU can't or reluctant to satisfy Prodi's underlying pledge to "close the hole among talk and reality". As the writing on European arrangement making sufficiently reports, the dynamic procedure at the EU level is profoundly unpredictable and a long way from being straight forward, paying little heed to what EU authorities imagines. The praise worthy endeavours planned for expanding straightforwardness conflict with political arrangements dependent on power elements: in this specific case, one can barely overlook part states' two-sided improvement participation systems and strategies. Regardless of an exceptionally advanced and technocratic language, asset portion (not just on account of the EDF) stays hazy, mirroring a triangular arrangement which joins EU part states' national advantages with requests by recipient nations and weights by a composite arrangement of interests campaigning in Brussels. Inside this specific circumstance, part states will in general consider EU's assignments as a simple expansion to their own 
mediation similarly as recipient nations organize reciprocal understandings (Stiglitz, Sen \& Fitoussi, 2019).

As indicated by Stiglitz et al (2019), Prime Minister Narendra Modi as of late came back from a voyage through Rwanda, Uganda and South Africa that incorporated a whirlwind of understandings and a discourse at the BRICS Summit in South Africa illustrating 10 core values for India's commitment in Africa. Behind the media barrage and talk, a pulled together Africa methodology is developing similar to the imperatives to its viable execution. The new system expands on India's delicate force in recorded, exchange, and social connections, especially with eastern Africa or in the new language, the western edge of the Indo-Pacific. While comprehensively intending to make sure about India's toehold on the mainland, secure access to assets, assemble markets for Indian merchandise and ventures, and bolster India's worldwide aspirations, the methodology is additionally centered around building collusions and separating India from China as an improvement accomplice. This comes when a few nations in the Indo-Pacific have fallen into an obligation trap with China (Stiglitz et al, 2019).

As indicated by Sumner and Tribe (2018), Aiming to redirect African nations from China's substantial centripetal power, India's primary instrument for actualizing this new system is an expansion being developed associations. Since it can't coordinate China's profound stashed foundation centered commitment in Africa, India has attempted to separate itself by connecting with its diaspora and private area connects to assemble improvement organizations, where India has a similar favorable position in Englishlanguage preparing and look into. India has additionally started a progression of India-Africa discussions and is working with Japan on an Asia Africa Growth Corridor. However amusingly, the biggest Indian advancement supports originate from India's Chinese-style credit lines, where India has submitted around 150 credit lines worth $\$ 10$ billion yet with lower payment rates than China. The methodology was in plain view during Modi's first stop in Rwanda, a nation that is viewed as an undeniably significant passage to Africa and one with which India now a vital organization has. Rwanda is the current seat of the persuasive African Union, where normal positions are received by the mainland. It is the third-quickest developing economy in Africa. Rwanda has additionally since quite a while ago been a dear of the West's commitment in Africa, giving it an out sized voice in the force passage ways of Europe and North America. At last, Rwanda has marked on to China's Belt and Road Initiative with 15 immense speculation ventures (Sumner and Tribe, 2018).

Modi declared India would open a high commission in Rwanda, marked seven MoUs, remembering for protection, and gave two credit lines of $\$ 100$ million each for water system works and mechanical parks. Modi's 
next stop in Uganda, which presently seats the East African Community, a gathering of six nations with a typical market and organized commerce game plans with different nations. In Uganda, Modi, with an enormous business appointment close behind, tended to a business occasion, just as the Indian diaspora, whose number of 50,000 give a false representation of their job in about $66 \%$ of the nation's GDP. Modi tended to the Ugandan parliament, a first by an Indian leader, submitted two credit lines for over $\$ 200$ million, and declared a few limit building and preparing programs. He additionally expanded participation on preparing between Uganda's military and the Indian Army (Tanzi; and Davoodi 2016).

As indicated by Tribe, (2013) Modi's last stop in South Africa to go to the tenth BRICS culmination drove home India's key commitment. Modi pointed the subtext at China: He said India is putting Africa at the highest point of its needs and is quick to manufacture associations that will free its potential as opposed to compel its future. Nixson, (2017) expressed that the India's Africa methodology is turning out to be more clear, inquiries concerning the viability of devices for actualizing it remain. India's improvement associations are far from organizing Africa and are famous for their low payment rates and moderate conveyance. Just four percent of Indian awards in 2017-18 were focused on Africa. Credit lines to Africa have a 40 percent payment rate, and of the $\$ 10$ billion in credit guaranteed between $2015-20$, just $\$ 1.5$ billion have been submitted through 2019 and a significantly littler division dispensed. India's new concessional financing plan, which finances private Indian organizations offering on African framework ventures, gives no indications of working a year after its declaration. These are huge obstructions as India tries to execute its new key organization with Africa and persuade nations that it can submit as well as convey.

It is pertinent to understand that global refocusing has to a great extent facilitated developmentalism which paves the way for Africa to grow with transformation and be in the reformed state to tackle emerging challenges and opportunities, such as climate change, food insecurity and the youth bulge. There is an urgent need to focus on the enablers of development which include; the infrastructure, regional integration, innovation, social inclusion and human security, and building active institutions.

\section{Global Refocusing and Challenges to achieving effective Africa development}

Not minding the already enjoyed optimism, Africa still faces some developmental challenges in the area of fragility, poverty reduction, structural transformation, limited integration, climate change, human development and governance. Some of these challenges hindering effective African development include; 
Persistent state fragility: significantly, the number of African countries have been growing much more slowly than the regional average because of their being in a fragile state(ACBF, 2011). These countries witness persistent conflict or weak socio-economic governance, which, to a great extent, make them unable to perform its essential functions. Among the 33 fragile states in the world, 20 are in Africa (The World Bank, 2012 and 2014). Excluding the oil-exporting countries, the rest Africaln fragile countries have experienced much slower real GDP growth than their non-fragile counterparts.

Data availability and its accuracy: " These have weakened strategic planning and the need to accurately time and sequence reforms. As it stands, the MDG and other related data have not always been available on time at the national as well as local levels as a result of inadequate statistical capacity. If they exist, they have been subjected to problems of inconsistency with international standards undermining comparison. At the same time, data transmission to and estimates made by international agencies and with the fact that countries did not produce all the data on MDGs annually constitute another layer of problems contributing to the observed data gaps which to a great extent has affected the economic growth and development of Africa"(Kararach, Hany \& Timothy, 2015).

Non-commensurate rapid growth with poverty reduction: In some of Africa's fast-growing countries, there is a disturbing number of people who are not witnessing rapid poverty reduction, and there is a tendency for inequality to arise (Kararach, 2011; Makoba, 2011). For instance, not minding the years of significant oil revenues, some African countries such as Equatorial Guinea (ranked 136), Nigeria (ranked 153) and Cameroon (ranked 150 out of 177) have posted among the lowest human development indicators in the world as of 2013 (UNDP, 2016). This entails that these countries have not been able to use their oil revenues to significantly improve the welfare of their poor citizens due to weak socio-economic governance that does not accommodate beneficiation.

Inadequate structural transformation: among those countries that have achieved both rapid growth and poverty reduction, such as Ghana, Rwanda and Ethiopia, poverty here fell from 46 per cent in 1995/96 to 30 per cent in 2011. There has been remarkably little structural transformation .i.e. they are still agricultural commodity-dependent. The share of manufacturing in GDP (11 per cent) or employment (8 per cent) is still quite low, and scarcely higher than it was before the growth phase due to limited structural transformation (UNECA, 2014).

Poor infrastructure and connectivity: In the recent time, many reasons are advanced by commentators as to why competitive development has not taken off in Africa - be it in manufacturing or agriculture or even services, but most of them revolve around the high costs of production and 
limited market integration on the continent. For example, in transport, immobilization before loading ranges from 13 hours in Central Africa to 6 hours in East Africa compared with 1.6 hours in France. The main driver of these high costs and the limited market is Africa's huge infrastructure deficit (UNECA, 2015). African exporters arguably face some of the highest transport costs in the world, especially in trying to ship goods from landlocked countries to the ports.

Business climate: Apart from infrastructure, several other factors drive up the cost of doing business in Africa. The World Bank's Doing Business indicators consistently rank African countries lowest among all regions of the world in most areas, with Mauritius the best performer ranking 19 out of 187, followed by South Africa in 39th place. There has been substantial limited progress in reforming business regulations where some countries such as Rwanda and Sao Tome and Principe are among the world's leading reformers in making it easier to undertake a business start-up, reforming the tax regimes. However, the fact remains that the costs of starting and running a business in Africa are, on average, the highest in the world (Mo Ibrahim Foundation, 2012).

Persistence of the informal sector or second economy: many Africans work in small farms and household enterprises where there are limited regulation and protection from poor working conditions. What is often called the informal sector or the second economy. For those low-income countries where there is data, the evidence showed that the private wage employment sector has been creating jobs faster than the growth of the GDP. However, that growth is from such a low base that it does not come close to absorbing the 7-10 million of new entrants into the labour force every year (The World Bank, 2015).

Weak human capital: Not minding a decade-and-a-half of Economic Growth and development across Africa, there are some poverty reduction and improvement in human capital indicators, Africa still at the lowest levels of Human Capital development in the world. The weak human capital base persists though the fact that considerable resources - from donors and African taxpayers have gone into the Health and educational sectors due to a range of reasons including a brain drain. Take health as an instance: achieving the goal of 'Health for All', as embraced in the developed countries 30 years ago, has proven to be difficult and a mirage, characterized by glaring inequities among Socio-economic groups and classes in Africa.

Weak regional integration: it should be highlighted that the economic unions in Africa are at each time dominated by the economies of a single country, and free movements of people limited to a few countries within each of these unions - Botswana and South Africa in southern Africa, Gabon in central Africa, Côte d'Ivoire and Nigeria in West Africa. There have been 
some levels of progress in that most regional integration agreements in Africa include provisions on the free movement of people and the right of residence (Kararach, 2014).

Government failure and inaction: arguably, the above problems are the result of poor governance or government failure to bring forth pro-poor reforms. Be it that losers are concentrated while winners are diffuse, or that paternalistic politics alter the constraints and incentives facing politicians, the system is in an equilibrium that has no intrinsic force for change or for delivering quality services. Indeed, services are delivered in a principal-agent nexus, whereby politics and representation, as well as accountability, affect service provision. Many of these issues have driven the conversations about the presence or lack thereof of a developmental state in Africa.

Climate change: currently, the adverse impacts of climate change pose a big threat to the sustainability of MDG achievement and broader African development through heightened risks of extreme weather events such as droughts and floods. Moreover, mitigating climate change presents a significant policy challenge for a region that faces enormous energy needs to power its development and industrialization. (Bond, 2011; Nhamo, 2011).

\section{Global Refocusing as an Opportunity for African in this $21^{\text {st }}$ Century Encouraging Good Governance and Political Stability}

In recent years, Africa has experienced more than 25 leadership changes, justifying the continent's wide push for greater accountability and democracy, which is credited to global refocusing on Africa. Countries like Mauritius, Botswana, Cape Verde, Namibia, and Ghana rank relatively high as politically stable, democratic countries. These countries, just as other rising majority rules systems across Africa, fill in as support to universal partners that steadiness can be accomplished all through the landmass. Across Africa, the administration has improved significantly since 2000. Thirty-four nations, home to 72 per cent of Africa's residents, have improved their administration execution in the course of the most recent ten years, and noteworthy upgrades have been found in interest, the rule of law, and rights, among different classifications. In recent years, numerous nations have likewise indicated enhancements in transparency and accountability (Nhamo, 2011).

\section{Responding To Conflicts And Crises}

The African Union has assigned 2019 as the "year of refugees, returnees, and internally displaced persons in Africa." This accord on the significance of African-drove answers for constrained displacement is demonstrative of the continent's drive to build a practical answer for migration issues. African Countries, despite everything, host the most significant number of refugees in the world; Uganda, Ethiopia, and Kenya on the whole host about 
2.8 million evacuees. Their Governments, regardless of having not many assets, have reacted rapidly and effectively to the deluge of displaced people from neighbouring nations.

\section{Improving health and reducing the impact of diseases}

Critical Public Health enhancements have been made in Africa in recent decades. There have been significant decreases in maternal and child deaths, and the occurrence of Chronic Malnutrition among Children under five has diminished by 10 per cent rate from 1995. Most nations are gaining acceptable ground on preventable childhood ailment and transferable illnesses. HIV/AIDS and malaria continue to have a widespread detrimental impact on Africans, but treatment options are improving. Across the Continent, life expectancies and healthy life expectancies are rising. Over the Continent, futures and solid futures are rising. To see Africa exclusively as a hotbed of ailment and craving is to overlook the noteworthy steps that nations and networks have made. African Governments and Health Workers are presently exceptionally dedicated to forestalling ailments, particularly Neglected Diseases that often tend to get short shrift, improving access to treatments, and finding better ways to deliver quality health care (Nhamo, 2011).

\section{Drastic Reduction of Social Challenges}

The size of people living in extreme poverty in Africa has declined over the past years, and for most countries, the outlook for poverty reduction is positive. Ethiopia, for example, is projected to almost eliminate extreme poverty by 2050 . However, the concentration of poverty 40 per cent of Africa's extremely poor is projected to live in Nigeria and the Democratic Republic of Congo by 2040 which entails that the next challenge will be on reducing poverty in all countries. Non-monetary dimensions of poverty have also been improving. Many countries, including some of Africa's poorest, are on track to make remarkable progress on the United Nation's Sustainable Development Goals (SDGs) by 2030. Since 2000, the number of African children enrolled in primary school has meaningfully appreciated from 60 million to 150 million.

\section{Conclusion}

Not minding the multiplicity of support to Africa across the globe, it is pertinent to note that Africa faces numerous challenges ranging from governance, leadership, corruption and issues of democracy. Africa's slowmotion of development could be partly blamed due to these challenges. These hindrances are many and real but can be met. Some countries did excellently in governance, but there is a need for improvement and more are still expected 
to be done if Africa is to succeed. Africa needs vibrant, dynamic and committed leaders to steer the affairs of the state.

Africa needs to improve its democratization; this is a loaded term, by it I mean giving citizens the right to express their views, and this will give the government the chance to know the problems and the ways they may be solved. Also, it encourages scrutiny of leaders and the way public wealth is distributed. Vibrant economic policies alongside with democratic policies that are based on African norms and values could lead to socio-economic development in Africa.

Institutional reform is necessary if Africa is to eradicate corruption. Institutional bodies should be independent of government control if corruption is to be combated and defeated in Africa. This would increase transparency and accountability. Strong political institutions will aid measures against corruption, open up the political and economic system to competition and have appropriate macroeconomic policies for development.

\section{Recommendations}

i. Policies should be made towards strengthening economic analysis and management as it will, to a great extent, facilitate sustainable development and poverty reduction across African.

ii. There should be improving governance through strong parliamentary framework aimed at encouraging social inclusion and the development of social capital and cohesive and stable society.

iii. There should be a thorough change of attitude from the corrupt initiative to excellent and reliable governance which will facilitate socio-economic growth and development in Africa thereby clearing the erroneous notion that Africa has a high influx of foreign aid with little result to show for it.

iv. All African countries should embrace E-Governanceas it will provide an alternative to Africa's bureaucratic challenges. This will reduce the Africa's administrative huddles drastically.

\section{References:}

1. ACBF (African Capacity Building Foundation) (2013) Africa capacity indicators 2013: $\quad$ Capacity development for natural resource management, Harare: ACBF.

2. Bond, R. (2013) The post-2015 development agenda: Reflections from the High-Level Panel Secretariat, Workshop report, July, Ottawa: North-South Institute. 
3. Kararach, G. (2011) The challenges of knowledge harvesting and the promotion of sustainable development for the achievement of the $M D G$ s in Africa, ACBF Occasional Paper no 12, Harare: ACBF.

4. Kararach George, Besada Hany \& Shaw, Timothy. (2015). Development in Africa: Refocusing the lens after the millennium development goals.

5. Makoba, J.W. (2011) Rethinking development strategies in Africa The triple partnership as an alternative approach - The case of Uganda, Oxford: Peter Lang.

6. Mo Ibrahim Foundation (2012) 2012 index of African governance. Available at http://ayyaantuu.com/wp-content/uploads/2012/10/2012IIAGsummary-report.pdf.Accessed 8th May, 2020.

7. Nhamo, G. (2011) 'REDD $(+)$ and the global climate negotiating regimes: challenges and opportunities for Africa', South African Journal of International Affairs, vol 18, no 3.

8. Nations Economic Commission for Africa (2012) Africa economic outlook report, Addis Ababa: UNECA.

9. Nixson, F. A. (2017) Economics and development studies, Oxford: Routledge.

10. Radice, H. (2011) 'The crisis and the global south: from development to capitalism', Economic and Political Weekly, vol 46, no 48, pp 2731.

11. Solheim, E. (2017) Climate, conflict and capital - Critical issues for the MDGs and beyond 2015', The Nordic Africa Development Policy Forum, 15 April (http://naiforum.org/2010/04/climate-conflictandcapital/).

12. Stiglitz, J.E., Sen, A. and Fitoussi, J.P. (2019) Report by the Commission on the Measurement of Economic Performance and Social Progress, New York: United Nations (www.stiglitz-senfitoussi.fr/documents/ rapport_anglais.pdf).

13. Sumner, A. and Tribe, M. (2018) International development studies: Theory and methods for research and practice, London: Sage Publications.

14. Tanzi, V. and Davoodi, H. (2016) Roads to nowhere: How corruption in public investment hurts growth,Washington, DC: International Monetary Fund.

15. Tribe, M. (2018) 'Aid and development: Issues and reflections', Strathclyde Discussion Papers in Economics, vol 13, no 9.

16. UNDP (2016) 2013 human development report - The rise of the South: Human progress in a diverse world, New York: UNDP. 
17. UNECA (2015) Economic Report on Africa 2014 - Dynamic industrial policy in Africa: Innovative institutions, effective processes and flexible mechanisms, Addis Ababa: UNECA.

18. UNCTAD (2013) World investment report 2013, Geneva: UNCTAD. Available at http://unctad.org/en/publicationslibrary/wir2013_en.pdf. Accessed $2^{\text {nd }}$ May, 2020.

19. World Bank, The (2012) Africa's Pulse: An analysis of issues shaping Africa's economic future, Vol 6.

20. World Bank, The (2014) Africa's Pulse: An analysis of issues shaping Africa's economic future, vol 10. Available at wwwwds.worldbank.org/

external/default/WDSContentServer/WDSP/IB/2014/10/23/000

Accessed $6^{\text {th }}$ May, 2020.

21. UNDESA (2014) World economic situations and prospects, New York: UN.

22. WHO (World Health Organization) (2015) Survey of the quality of selected antimalarial medicines circulating in six countries of subSaharan Africa Geneva: WHO. Available at www.who.int/medicines/publications/WHO_QAMSA_report.pdf. Accessed $1^{\text {st }}$ may 2020.

23. World Bank, The (2010) Africa's infrastructure: A time for transformation, Washington DC: The World Bank. 